\title{
Gåtefull medisinsk kildebruk
}

\author{
I løpet av de siste 30 årene har jeg som student, sensor, opponent, fagfelle, eller som en helt vanlig nysgjerrig \\ leser av akademiske tekster sett en del pussige ting. Hva som er «pussig» er naturligvis avhengig av øynene \\ som ser. Her skal jeg begrense meg til noe som de aller fleste, på en eller annen måte eller i en eller annen \\ grad, vil oppfatte som rart: kildehenvisninger som ikke viser hvor kilden er hen, eller som ikke viser hvor man \\ skal hen i kilden som det er vist til.
}

a Engelsk oversettelse av hele artikkelen på www.tidsskriftet.no

\section{Ole Bjørn Rekdal}

obr@hib.no

Avdeling for helse- og sosialfag

Høgskolen i Bergen

Utgangspunktet for problemstillingen er ganske enkel: Når jeg leser et mer eller mindre vitenskapelig arbeid (A), hender det at jeg fatter interesse for en kilde (B) som det henvises til i A. Det kan være mange ulike og gode grunner for en slik interesse, og er den stor nok, så anskaffer jeg meg kilden. Bakgrunnen for interessen er som regel at det som $\mathrm{A}$ hevder med henvisning til B tyder på at jeg kan lære noe av B, og som jeg kanskje kan få bruk for i en eller annen sammenheng. I andre tilfeller er det kanskje en porsjon skepsis ute og går. Er det sant at det som A hevder står i B, virkelig står i B? Går det an å tolke B på en annen måte enn det som $\mathrm{A}$ har gjort?

Uansett blir det viktig å få tak i B,og å finne ut hva som står der. I denne prosessen kan man komme ut for ulike typer problemer og utfordringer. De mest alvorlige er når henvisningen er så feilaktig eller mangelfull at det er umulig å finne frem til kilde B. Det er liten grunn til å dvele ved akkurat denne typen kildehenvisninger, siden alle lesere er enig $i$ at dette er regelrett dårlig gjort - og det $\mathrm{i}$ opptil flere betydninger av uttrykket. Det er heller ikke verdt å bruke tid og kostbar spalteplass på enkelte medisineres uvilje mot å oppsøke primærkilder, og på redaktører som, ved ikke å slå ned på det, lar sine tidsskrifter bli en boltreplass for vandrehistorier og selskapsleker. Hviskeleken er et glimrende eksempel på hva som kan skje med budskap som passerer gjennom mange ledd, og dermed også en god illustrasjon på hvorfor man bør tilstrebe bruk av primærkilder innen akademia.

Selv om de fleste medisinere har fått med seg poenget med at det er farer forbundet med å bruke sekundærkilder, betyr ikke dette at mulighetene for lek og ablegøyer er borte. Når de henviser til en bok, eller et annet omfattende eller komplekst kildedokument, benytter for eksempel mange seg av muligheten til å bake inn gåter av ulike vanskelighetsgrader i kildehenvisningene sine.

\section{Gåtefulle kildehenvisninger}

Hovedpoenget i denne leken består i å forsøke å gjette seg til hvor i boken man finner det som forfatteren har latt seg inspirere av. Forfatteren har nemlig ikke oppgitt noe sidetall i kildehenvisningen sin, og leseren

\section{«Dette dreier seg ikke bare om irriterende slurv, med bortkasting av lesernes tid og krefter som resultat»}

er overlatt helt og holdent til seg selv med å løse gåten. Det er ingen der som kan si «tampen brenner», og løsningen finnes heller ikke oppgitt nederst på siden med liten skrift, slik for eksempel historikere pleier å gjøre. Løsningen kommer ikke engang i neste nummer av tidsskriftet, som menn og kvinner av min generasjon er vant til å forvente fra tegneserier og ukeblader. Med andre ord, klarer man ikke løse gåten, forblir den uløst for evig og alltid - med mindre man tar drastiske virkemidler i bruk

Med e-post er det blitt langt enklere å kontakte forfatteren direkte og spørre på en høflig måte om flere ledetråder slik at man kan finne frem til hva henvisningen hinter om. Er man riktig heldig treffer man på en vennlig forfatter med god hukommelse eller med sysakene i orden, og som kjapt og greit kan gi oss det manglende elementet $\mathrm{i}$ adressen $-\mathrm{i}$ dette tilfellet sidetallet. Egentlig burde vi alle være flinkere til å benytte oss av denne muligheten, og ikke bare fordi vi ønsker å finne frem til kunnskap og interessante poenger i kilder vi kommer over. En forfatter som overstrømmes av slike henvendelser - kanskje også med kopi til redaktøren - vil sannsynligvis lære noe viktig om kildehenvisninger, og vil forhåpentligvis tenke seg om en gang til før hun/han igjen sender sine lesere ut i tåkeheimen.

En annen måte å løse problemet knyttet til manglende sidetall på, er å bruke kniv ikke på gåtesmeden, men på boken hun/han henviser til. Man kan skjære ryggen av den, og så kjøre de løse arkene gjennom en skanner med arkmater. Etter dette kan man bruke et såkalt OCR-program (Optical Character Recognition) på den resulterende elektroniske filen, og vips, så har man mulighet til å bruke ulike søkeord for å finne frem til det man leter etter.

For å si som sant er, har jeg i flere tilfeller av frustrasjon, for ikke å si desperasjon, benyttet meg av denne strategien. Det innebærer naturligvis at jeg har maltraktert bøker jeg har betalt mye penger for, men det har likevel vært meget god ressursforvaltning sett $\mathrm{i}$ forhold til det antall timer jeg måtte ha brukt hvis jeg skulle fortsette å bla frem og tilbake i disse bøkene.

Dette dreier seg ikke bare om irriterende slurv, med bortkasting av lesernes tid og krefter som resultat. Når slike gåter forblir uløste, representerer de også effektive hindre for viktige drivkrefter innen vitenskapelig utvikling: kumulativ kunnskapsproduksjon og etterprøving av påstander og tolkinger.

\section{Størrelsen er viktig}

Det finnes en rik litteratur som tyder på at det kan gå fort i svingene når medisinere skriver sine kildehenvisninger og litteratur- 


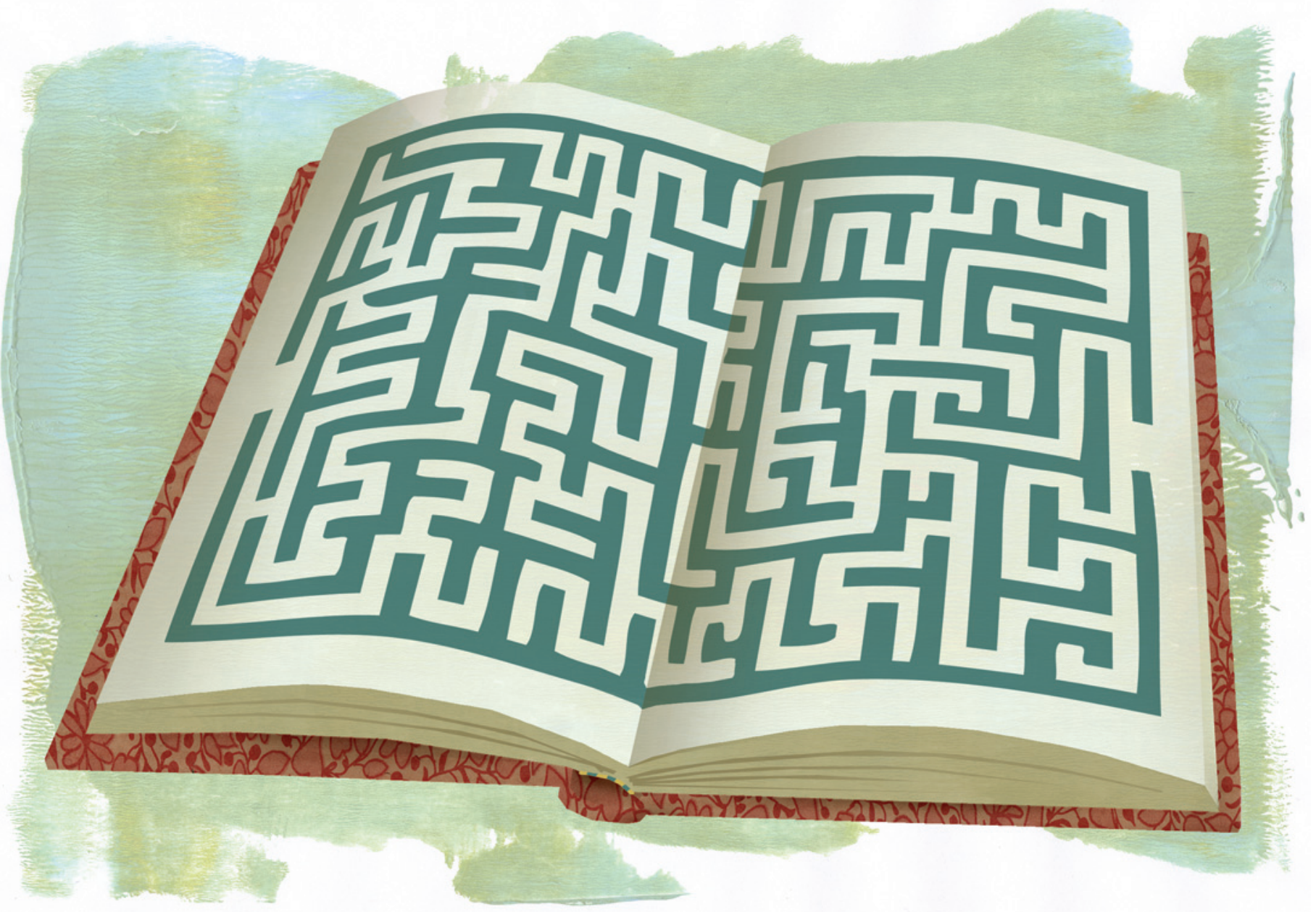

Illustrasjon Stein Løken

lister. For å være ærlig lar jeg meg verken overraske eller sjokkere av den omfangsrike litteraturen om «reference accuracy» eller «citation errors» innen medisin, annet enn av at såpass mange finner det verdt å bruke så mye tid på å jakte på kommafeil og feilaktige forkortelser, i stedet for å bruke kreftene på å konsentrere seg om noe langt mer interessant: om det som A hevder står i B, faktisk står der. En forutsetning for å kunne avgjøre dette viktige spørsmålet er naturligvis at det er innen rimelighetens grenser mulig å finne frem til kilde B, og den delen av B det hele dreier seg om.

Kildene som medisinere baserer seg på, er vanligvis små artikler som det er fort gjort å finne frem i selv om ikke sidetall er oppgitt i henvisningen. Det finnes imidlertid mange medisinere som fortsatt leser bøker, og som i tillegg av og til henviser til dem som kilder. Det er her problemene oppstår; når B er en stor tykk bok, og det i A ikke er gitt leseren noe hint om hvor man bør begynne å lete eller lese. Kort sagt, A viser til noe i B uten å oppgi det som heter «locator» (heretter kalt lokator), for eksempel et sidetall eller hva slags kapittel eller seksjon det dreier seg om. Det er forskjell på en artikkel på 3000 ord og en bok på 1010 sider. I farten, hvis farten er stor nok, kan det være lett å glemme akkurat dette poenget.

Denne typen henvisningspraksis, hvor lokatorene mangler, er såpass utbredt blant medisinere at man ikke kan forklare fenomenet som et utslag av hastverk eller ulike former for økonomisering av trykksverte og papir. I mange tilfeller opptrer slike gåtefulle kildehenvisninger konsekvent gjennom en hel publikasjon, og noen ganger gjennom en hel akademisk karriere. Dette må dreie seg om noe langt mer alvorlig enn enkeltstående tilfeller av malplassert humor eller andre typer menneskelig svikt.

\section{Hva sier publiseringsmanualene?}

AMA manual of style: a guide for authors and editors er et av flere viktige veiledende dokumenter for skrivende medisinere, og svaret vi søker er temmelig klart formulert i vendinger som ikke overlater mye til tilfeldighetene (1). Viser man til en spesifikk side $\mathrm{i}$ en bok, skal dette sidetallet oppgis på slutten av referansen helt bak i litteraturlisten (s. 52-3). Trenger man å vise til samme boken flere ganger (s. 44), så skal kilden oppgis bare én gang bak i listen, og eventuelle sidetall skal da settes sammen med de henvisende sluttnotene inne i teksten, slik som dette: ${ }^{1(\mathrm{p} 44)}$ Her henviser jeg altså til side 44, én av de 1010 sidene i kilde nummer 1, og som i dette tilfellet er AMA manual of style.

Mange medisinske tidsskrifter viser imidlertid til en annen autoritativ kilde i sine forfatterveiledninger: International Committee of Medical Journal Editors og deres Uniform Requirements for Manuscripts Submitted to Biomedical Journals (2). Her er det ikke like enkelt å finne frem til informasjonen vi søker i dette tilfellet. Først må man klikke seg videre til en annen nettside kalt Citing Medicine hos National Library of Medicine (NLM), men når man kommer frem dit, er det til gjengjeld virkelig mye man kan boltre seg i (3).

Her finner man igjen dette med at sidetall eller andre lokatorer skal oppgis på slutten av referansen bak i litteraturlisten når man refererer til «parts of books». Hvis man siterer ordrett en setning, omskriver et avsnitt, eller gjengir en konkret og avgrenset påstand fra en bok, bruker man nødvendigvis en del av (eller «part of») en bok, og saken skulle derfor i utgangspunktet være grei. Problemet er at eksempelsamlingen knyttet til dette punktet er egnet til å skape usikkerhet. Det blir ikke klinkende klart om direkte sitat, parafrasering eller en konkret påstand skal behandles 
som «part $[\mathrm{s}] »$ på lik linje med andre «parts» (som for eksempel tabeller og figurer), rett og slett fordi det ikke finnes noen tilfeller av det i den formidable eksempelsamlingen som ledsager kapitlet (4).

Løsningen på hvordan man kommer videre til neste post i dette rebusløpet, ligger innbakt $\mathrm{i}$ introduksjonen til NLMs nettsider. Her gjøres det klart at Citing Medicine baserer seg på dokumenter utarbeidet av International Organization for Standardization (5) og National Information Standards Organization (6). Vi har til slutt funnet frem til to av steintavlene som danner fundamentet for Citing Medicine; og disse autoritative kildene slår begge kort og greit fast at man skal oppgi lokatorer når man viser til en avgrenset del av et større verk, som for eksempel en bok (5:9;6:43).

Man trenger ikke lete lenge i prestisjetunge medisinske tidsskrifter før man kommer over eksempler på medisinere som ikke følger disse reglene, og som alle har hatt fagfeller og redaktører som har latt dem få lov til å gjøre det. Hva kan være årsaken til fenomenet?

Den mest åpenbare forklaringen er at mange medisinere ikke er klar over hva ISO (5), NISO (6) og AMA manual of style (1) sier om saken, noe som på sett og vis er rimelig tatt $\mathrm{i}$ betraktning hvor vanskelig tilgjengelig de to første kildene er, og hvor stor og tykk den tredje er. Så enkelt er det nok neppe, dessverre. Selv om man aldri har sett disse kildene, er det rimelig å forvente at en forfatter ved hjelp av god gammeldags sunn fornuft burde skjønne at det ikke bare kan være nyttig, men i enkelte tilfeller fullstendig avgjørende for en leser at lokatorer er oppgitt for et kildedokument som er så omfattende som en bok. De fleste av oss bruker denne logikken daglig i en lang rekke ulike sammenhenger, helt uten å sette spørsmålstegn ved den. Trenger vi opplysninger for å finne frem til et bestemt hus, vil vi for eksempel ikke bare ha gatenavnet, men også husnummeret, og det er spesielt viktig å ha dette nummeret når gaten er lang eller kronglete å finne frem $i$.

\section{Den store gåten}

I enkelte tilfeller kan bevisst utelatelse av viktige og nyttige lokatorer være en fullt ut rasjonell og klok handling. Det kan være mange gode grunner til at en forfatter ikke ønsker at leseren skal finne frem til, eller $i$, kilden det henvises til. Slike hindre er det spesielt lurt å legge inn i tilfeller hvor man tøyer grenser for redelighet, plagierer eller jukser på andre måter, for eksempel ved å dikte opp ting, lyve, forvrenge, eller låne andres formuleringer uten å bruke anførselstegn. Samme strategi kan brukes for å skjule at man har hatt det travelt, eller av andre grunner har valgt å basere seg på sekundærkilder i tilfeller hvor man slett ikke burde ha gjort det.

Et tredje tilfelle hvor det kan være lurt å legge inn hindre for kritiske lesere, er når kildehenvisninger brukes som placebo eller som tryllemiddel. En kildehenvisning kan være et nyttig verktøy som kan gi et skinn av autoritet og kraft til svake punkter med skrikende behov for nettopp dette, og kan også fungere utmerket til å forføre lesere til å tro at kompliserte problemstillinger er langt enklere og behagelig å forholde seg til enn det de rent faktisk er. Når man bruker kildehenvisninger som placebo eller som et forenklende tryllemiddel, er sidetall og andre lokatorer ikke bare overflødige. Nøyaktige og fullstendige kildehenvisninger reduserer også sjansene for at trylleriet skal lykkes, akkurat som placeboeffekten kan bli borte hvis man lett kan finne ut av hva man faktisk har fătt i seg. Sagt på en litt mer brutal måte: nøyaktige kildehenvisninger, inkludert nødvendige lokatorer, gjør det langt enklere å avgjøre om et byggverk egentlig bare er et makkverk.

For dem som har rent mel i posen, skulle det ikke være noen grunn til å tåkelegge kil- dene sine. Her er vi fremme ved det som for meg står som den største gåten av dem alle: Hvorfor man finner ubrukelige kildehenvisninger i ellers briljante medisinske publikasjoner som åpenbart er basert på en formidabel og grundig arbeidsinnsats utført av en rekke tvers igjennom redelige mennesker. Uansett hva forklaringen på fenomenet måtte være - god formidling av vitenskap og kunnskap er det definitivt ikke.

Jeg takker Odd Mørkve, Kjersti Hopland og Marte Jürgensen for kritiske og konstruktive kommentarer.

\section{Ole Bjørn Rekdal (f. 1959)}

er sosialantropolog, dr.polit. og førsteamanuensis ved $\mathrm{H} \varnothing$ gskolen i Bergen. Ingen oppgitte interessekonflikter.

\section{Litteratur}

1. American Medical Association. AMA manual of style: a guide for authors and editors. 10. utg. New York: Oxford University Press, 2007.

2. ICMJE. Uniform requirements for manuscripts submitted to biomedical journals. http://www.icmje.org/ (19.9.2011)

3. Patrias K. Citing medicine. The NLM style guide for authors, editors, and publishers. http://www.ncbi.nlm.nih.gov/books/NBK7256/ (19.9.2011)

4. Patrias K. Citing medicine. The NLM style guide for authors, editors, and publishers. Chapter 2 Books. http://www.ncbi.nlm.nih.gov/bookshelf/ br.fcgi?book=citmed \& part=A34155 (19.9.2011)

5. ISO. Documentation - bibliographic references content, form and structure. International standard. ISO; 690. 2. utg. Genève: International Organization for Standardization, 1987

6. NISO. Bibliographic references. ANSI/NISO Z39.29-2005. Bethesda, MD: National Information Standards Organization, 2005.

Mottatt 2.6. 2011, første revisjon innsendt 28.8. 2011, godkjent 6.10. 2011. Medisinsk redaktør Petter Gjersvik. 